AGH Journal of Mining and Geoengineering • Vol. $37 \bullet$ No. $2 \bullet 2013$

http://dx.doi.org/10.7494/mining.2013.37.2.9

Stanisław Budzyń ${ }^{*}$, Janusz Jakóbiec*, Barbara Tora*, Wiestaw A. Żmuda*

\title{
LABORATORY ANALYSIS OF RUBBER WASTES IN ORDER TO THEIR UTILIZATION IN ENERGY SECTOR**
}

\section{Introduction}

The pyrolysis of rubber waste such as used tyres, transportation belts, rubber packing, rubber industry wastes etc. is one of the one of the basic methods used for the disposal of waste rubber, which provides the possibility of re-utilizing the entire product, especially, in terms of energy [1].

Many companies around the world are carrying out the pyrolysis of used car tyres and offer their own solutions concerning technology [3]. However, most of these proposals are not economically viable. Several European projects have not been put into effect due to the unprofitability of the investment. Most of the various different types of installation can be found operating in Asia. In South Korea, successful installations manufactured by American companies, Products Carbon International and Titan Technologies are in operation, along with another by Titan Technologies in Taiwan. The Swiss company Alyconalso has an installation in Taiwan. In Poland the pyrolysis process for re-utilizing used tyres was carried out in the nineteen seventies by the Institute for Chemical Processing of Coal, however, at that time the technology was not profitable enough [2].

The products recovered through pyrolysis are: carbonization product, oil and gas. Carbonization product accounts for $45 \%$ of pyrolysis recovery, but is very difficult to re-use in industry due to additional material which serve as tyre-strengthening (metal and textiles) as well as some ingredients of rubber which, during pyrolysis, stay in the solid product and lower investment profitability. Therefore an examination of the pyrolysis process was undertaken, concerning only the pure rubber granulated product obtained from the disintegration of used tyres and devoid of any additional materials like textiles and metal elements.

\footnotetext{
* AGH University of Science and Technology

** Paper was realized as part of statutory work AGH no. 11.11.210.213.
} 


\section{Research}

\subsection{The pyrolysis analysis laboratory equipment}

The installation used for the pyrolysis process of the granulated product is shown on Figure 1. A substantial element is a retort made of heat-resistant steel, composed from two separate pieces jointed with screw fixings. The retort has a diameter of $90 \mathrm{~mm}$ and height equal to $700 \mathrm{~mm}$. At the bottom of the retort, the sample of granulated rubber product was placed. The upper section has a pipe delivering water and a pipe which removes the pyrolysis gases. The retort is placed in a $10 \mathrm{~kW}$ electric furnace which provides the uniform temperature throughout the entire height of the load and maintains heat rate stability at a set level. The temperature is measured using a thermocouple placed in the central part of the load and on its surface. The retort's end consists of a pipe which deliverswater to the load and a pipe which carries volatile matter away. Water is transported to the retort using peristaltic pump, which allows foraccurate measurement and dosage control. Pyrolytic gas is thencondensed in the receivers.

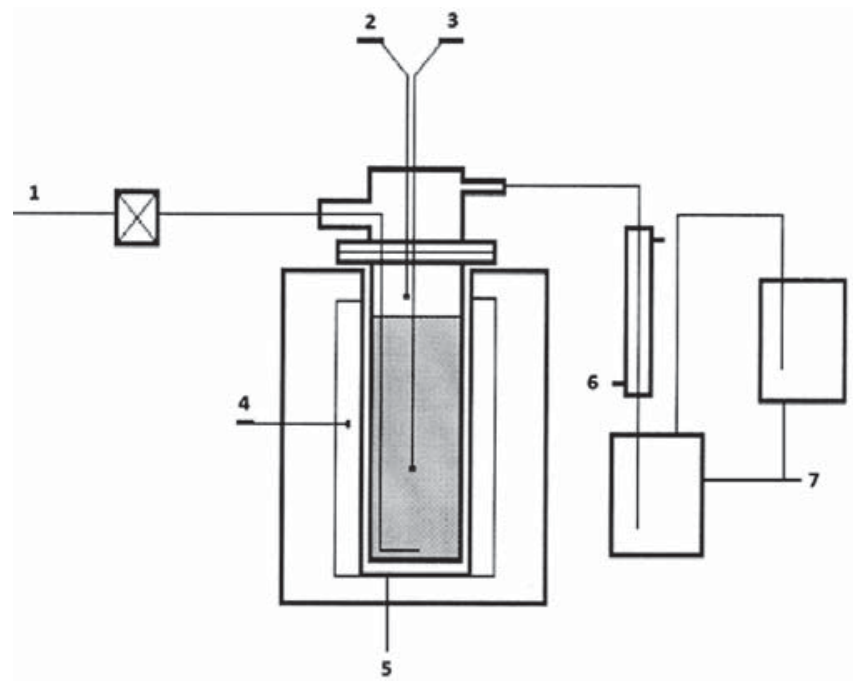

Fig. 1. Instalation for pyrolysis:

1 - dosing pump, 2, 3, 4 - thermoelement,

5 - retort, 6 - cooler, 7 - collecting oil

\subsection{Examination of pyrolysis of rubber granulate}

A sample of rubber granulate weighting approximately $430 \mathrm{~g}$ was prepared for the tests. After weighing, the sample was poured into the retort which was then closed and put into the furnace. After connecting the water supplying ducts and carrying off the volatile matter 
ducts the furnace was switched on, taking the heating rate into account. The water supply wasswitched on as soon as temperature inside the load reached $100^{\circ} \mathrm{C}$. After reaching the terminal temperature, which had been pre-set, and after a stabilization period, the furnace was switched off. After cooling, the retort was removed from the furnace and the solid residue extracted was then weighed. The oil obtained from the pyrolysis process was also collected in a receiverand weighed.

Table1 shows results from tests on energetic properties of rubber granulate conducted in $450,500,550$ and $600^{\circ} \mathrm{C}$. The pyrolysis process continued until oil collection ceased. At this point the furnace was switched off.

\section{TABLE 1}

Energetic properties of rubber granulate

\begin{tabular}{|c|c|c|c|c|c|c|c|c|}
\cline { 2 - 8 } \multicolumn{1}{c|}{} & $\begin{array}{c}\boldsymbol{W}^{a}, \\
{[\%]}\end{array}$ & $\begin{array}{c}\boldsymbol{V}^{a}, \\
{[\%]}\end{array}$ & $\begin{array}{c}\boldsymbol{A}^{a}, \\
{[\%]}\end{array}$ & $\begin{array}{c}\boldsymbol{S}^{a}{ }_{\boldsymbol{t}}, \\
{[\%]}\end{array}$ & $\begin{array}{c}\boldsymbol{C}^{a}, \\
{[\%]}\end{array}$ & $\begin{array}{c}\boldsymbol{H}^{a}, \\
{[\%]}\end{array}$ & $\begin{array}{c}\boldsymbol{Q}^{a}{ }^{a}, \\
{[\mathbf{\% J} / \mathbf{k g}]}\end{array}$ & $\begin{array}{c}\boldsymbol{Q}^{a}{ }{ }, \\
{[\mathbf{k J} / \mathbf{k g}]}\end{array}$ \\
\hline Granulate & 0.4 & 64.6 & 6.3 & 2.08 & 79.70 & 6.91 & 34264 & 32728 \\
\hline
\end{tabular}

Nomenclature: $W$ - moisture, $V$ - volatile matter, $A$ - ash content, $S$ - sulphur content, $C$ - carbon content, $H$ - hydrogen content, $Q_{s}$ - calorific value, $Q_{i}$ - net calofific value, $a$ - index - analytical.

Table 2 shows the yields of pyrolytic products at different temperatures during the process. With the increase of temperature, the amount of oil obtained increases while the amount of solid carbonization product decreases.

TABLE 2

Yield of pirolysis products vs temperature

\begin{tabular}{|c|c|c|c|c|}
\hline \multirow{2}{*}{ Product of pirolysis } & \multicolumn{4}{|c|}{ Temperature of pyrolysis, $\left[{ }^{\mathbf{0}} \mathrm{C}\right]$} \\
\cline { 2 - 5 } & $\mathbf{4 5 0}$ & $\mathbf{5 0 0}$ & $\mathbf{5 5 0}$ & $\mathbf{6 0 0}$ \\
\cline { 2 - 5 } & \multicolumn{4}{|c|}{ Share, [\%] } \\
\hline Carbonizate & 43.5 & 43.0 & 37.7 & 36.8 \\
\hline Oil & 47.0 & 48.1 & 52.4 & 52.5 \\
\hline Gas & 9.5 & 8.9 & 9.9 & 10.7 \\
\hline
\end{tabular}

Table 3 demonstrates the energy values of the various carbonization products. The value of the carbonization product decreases with increasing temperature which is associated with a reduction of carbon and hydrogen content. 
TABLE 3

Energetic properties of carbonizate

\begin{tabular}{|c|c|c|c|c|c|c|c|c|}
\hline $\begin{array}{c}\text { Temperature } \\
\text { of pirolysis, } \\
{\left[{ }^{\circ} \mathrm{C}\right]}\end{array}$ & $\begin{array}{l}\mathrm{W}^{\mathrm{a}}, \\
{[\%]}\end{array}$ & $\begin{array}{c}\mathbf{V}^{\mathbf{a}}, \\
{[\%]}\end{array}$ & $\begin{array}{c}\mathbf{A}^{\mathrm{a}}, \\
{[\%]}\end{array}$ & $\begin{array}{l}\mathrm{S}_{\mathrm{t}}^{\mathrm{a}}, \\
{[\%]}\end{array}$ & $\begin{array}{l}\mathrm{C}^{\mathrm{a}}, \\
{[\%]}\end{array}$ & $\begin{array}{l}\mathbf{H}^{\mathrm{a}}, \\
{[\%]}\end{array}$ & $\begin{array}{c}\mathbf{Q}^{\mathrm{a}}{ }_{\mathrm{s}} \\
{[\mathrm{kJ} / \mathrm{kg}]}\end{array}$ & $\begin{array}{c}\mathbf{Q}^{\mathrm{a}}{ }_{\mathrm{i}} \\
{[\mathrm{kJ} / \mathrm{kg}]}\end{array}$ \\
\hline 450 & 0.4 & 13.3 & 14.5 & 2.22 & 81.07 & 1.80 & 29597 & 29194 \\
\hline 500 & 0.6 & 11.4 & 14.6 & 2.26 & 80.62 & 1.57 & 29124 & 28767 \\
\hline 550 & 0.7 & 2.0 & 16.6 & 2.45 & 79.30 & 0.59 & 27676 & 27530 \\
\hline 600 & 0.7 & 1.8 & 16.7 & 2.42 & 78.82 & 0.60 & 27569 & 27421 \\
\hline
\end{tabular}

Table 4 shows metal content found in ash left over from carbonization of the product, while

TABLE 4

Metals content in ash from carbonizate, $[\mathrm{mg} / \mathrm{kg}]$

\begin{tabular}{|c|c|c|c|c|c|c|c|c|c|c|}
\hline $\mathbf{C r}$ & $\mathbf{C d}$ & $\mathbf{P b}$ & $\mathbf{C o}$ & $\mathbf{A s}$ & $\mathbf{H g}$ & $\mathbf{S n}$ & $\mathbf{C u}$ & $\mathbf{M n}$ & $\mathbf{V}$ & $\mathbf{T i}$ \\
\hline 363.32 & 6.58 & 262.12 & 751.44 & 11.02 & 0.51 & 11.33 & 799.83 & 119.73 & 18.99 & 248.49 \\
\hline
\end{tabular}

Table 5 provides information regarding oxide content in the ash left over from carbonization of the product. Measuring content in leftover ash is important for determining the results of fuel burning, on the basis of carbonization of the product.

TABLE 5

Oxides content in ash from carbonizate, [\%]

\begin{tabular}{|c|c|c|c|c|c|c|c|c|c|}
\hline $\mathrm{Na}_{\mathbf{2}} \mathbf{O}$ & $\mathrm{K}_{\mathbf{2}} \mathbf{O}$ & $\mathrm{ZnO}$ & $\mathrm{Fe}_{\mathbf{2}} \mathbf{O}_{\mathbf{3}}$ & $\mathbf{S i O}_{\mathbf{2}}$ & $\mathbf{C a O}$ & $\mathbf{M g O}$ & $\mathbf{A l}_{\mathbf{2}} \mathbf{O}_{\mathbf{3}}$ & $\mathbf{P}_{\mathbf{2}} \mathbf{O}_{\mathbf{5}}$ & $\mathbf{S O}_{\mathbf{3}}$ \\
\hline 0.80 & 0.40 & 33.85 & 0.785 & 48.60 & 5.21 & 0.52 & 1.152 & 0.95 & 7.65 \\
\hline
\end{tabular}

\section{Summary}

Due to high heating values, reaching about $30 \mathrm{MJ} / \mathrm{kg}$, carbonization products may be used as the base ingredient for alternative fuel production. Various recipes based on the carbonization product are presented in the patent [4]. To prepare mixtures, carbonization products which amounted to about $70 \%$ mixed with add-ons in the form of stabilized sewage sludge, bone meal or sorted municipal waste were used. The alternative fuel (solid secondary fuel) obtained has a heating value in the range of $22-24 \mathrm{MJ} / \mathrm{kg}$. 
The high calorific value of the basic component, obtained through the carbonization process, allows for the production of alternative fuel with a significant calorific value range, which can also be customized for individual recipients. Due to the negligible moisture values and low content of volatile matter, waste which is normally characterized with low efficiency and generally accepted as economically unviable can also be used as a component in this alternative fuel. Carbonization product has a much better and more stable energetic properties than waste, as well as physical properties which do not cause problems in alternative fuel preparation technology. Another use of carbonization product obtained throughtyre pyrolysis, may be the production of lignite and peat briquettes. As it is known the lignite and peat are characterized with high moisture content as well as volatile matter. The utilization of carbonization product, in order to produce lignite and peat briquettes, could also significantly improve these energetic parameters.

\section{REFERENCES}

[1] Stelmach S.: Potencjalne metody zagospodarowania karbonizatów z opon samochodowych, Archiwum Gospodarki Odpadami i Ochrony Środowiska, ISSN 17334381, Vol. 13 nr 3 (2011), str. 37-52.

[2] Stelmach S., Wasielewski R., Figa J.: Badania pirolizy zużytych opon samochodowych, Praca zbiorowa pod red. Wandrzasza J.W. i Pikonia K.: Paliwa z odpadów V, Helion, Gliwice, 2005.

[3] Tora B.: Wybrane sposoby wykorzystania produktów pirolizy odpadów, Przegląd Górniczy. ISSN 0033-216X - 2013 t. $69 \mathrm{nr} 3$ s. 163-166.

[4] Tora B., Budzyń S., Żmuda W.A., Fecko P., Kriz V.: Sposób wykorzystania olejów po pirolizie odpadów organicznych — [Method for using oils after the pyrolysis of organic waste] / patent PL 393095 A1 — Zgłosz. 2010.11.30. Opubl. 2012.06.04.

[5] Sposób wytwarzania ukształtowanego paliwa stałego z materiałów odpadowych, Patent PL 394987

[6] Depta G., Tora B., Żmuda W., Budzyń S.: Sposób wytwarzania ukształtowanego paliwa stałego z materiałów odpadowych Pantent PL 394987, 2012. 